\title{
EFFECT OF SEAWEED EXTRACT (ACADIAN) ON SOME FLOWERING CHARARCTRESTICS FOR TWO CULTIVARS OF SUMMER SQUASH Cucurbita pepo L.
}

\author{
Fathel, F. Alhadede Kabas, B. Abdullah
}

Hort. and Land Scape Dept., College of Agriculture and Forestry, University of Mosul. Iraq

Email : fathel_way@yahoo.com

\begin{abstract}
This experiment carried out at vegetables field of Horticulture and landscape department. College of Agriculture and Forestry. University of Mosul during the spring season (2018). The experiment included two factors. First was two hybrids of summer squash (MARVEL F1) and (ISMALIA F1), the second factor was included the seaweed extract (Acadian) at three concentrations of $\left(0,2\right.$ and $\left.4 \mathrm{gm} \cdot \mathrm{L}^{-1}\right)$. thus the experiment included 6 treatments $(2 \times 3)$. The experiment carried out in the field using split-plots system in R.C.B.D design the hybrids placed in the main plots while the sub plots included Acadian extract levels each treatment repeated three times. Analysis of variance and Duncan's multiple range test at 0.05 were applied for all recorded data. The results could be summarized as follows: Marvel and Ismailia hybrid plants did not differ in all studied flowering growth characteristics (appearance date of the first male and female flower (day) on the plant, number of male and female flowers (flower.plant ${ }^{-1}$ ), sexual ratio, set ratio of female flowers). The Acadian extract factor in both hybrids used showed it as the important and influencing factor in some studied traits, as its use led to significant results in some traits of flowering growth, and the treatments of Acadian extract at 2 and $4 \mathrm{~g}$. $\mathrm{L}^{-1}$ concentration did not differed between them significantly in most of the effects.
\end{abstract}

Keywords: Acadian, Summer squash, Hybrids, Male flowers, Female flowers.

Received: $29 \backslash 2 \backslash 2020 \quad, \quad$ Accepted: $23 \backslash 4 \backslash 2020$

\section{INTRODUCTION}

Summer squash (Cucurbita pepo L.), Which belongs to Cucurbitaceae family includes many summer vegetables crops important in terms of nutritional and medical vegetable, rich in nutrients as it contains vitamins, carbohydrates, fulvic acid, amino acid and mineral elements in particular potassium and a high proportion of fiber

The research is a part of M.Sc. Thesis in the case of the first researcher. 
hasmany medicinal uses, the most important of which comes from seed oil, which contains steroid compounds that enter the pharmaceutical industry used to treat prostate tumor (Gossell et al., 2007 and Khadem and Hussein, 2015).

The trend of modern research has been to raise the efficiency of agricultural production by using high-yield hybrid varieties (Ibrahim, 2007). The hybrid of scallop squash varies in terms of productivity per unit area according to their genetic capacity and conditions during the period of growth and production because of the economics of production to provide hybrid varieties, it is characterized by high productivity and good quality specifications for fruits which must be accepted by the consumer (Kolato and Balbierz, 2015).

In a study by Nesmith et al. (1994) on five varieties of squash in the southern United States (lenondrop, senator, dixie, elite and meigs) he observed the significantly superiority of the Dixie variety only in the number of female flowers, set ratio, and the sexual ratio over the rest of varieties. Shalaby et al. (2003) established in Assiut to elect five inbred lines of zucchini, the zucchini variety, which was elected under adverse climatic conditions to produce female flowers. It was noted that the five inbred lines significantly outpaced the Alexandrian variety in the sexual ratio as a result of the increase in female flowers and also the set ratio. Ercon and Kurum (2003) reported in their study of five inbred lines of squash that Atlant 7 (23) variety was significantly superior in number of female flowers and sexual ratio compared to the rest of the inbred lines. In a study by Mohamed (2003) in Egypt on five varieties of squash to indicate that the effect of varieties on the number of female flowers he found that all varieties significantly outperformed as compared to the Alexandrian variety in the number of female flowers, sexual ratio and the percentage of the set ratio. Radiya (2004) found in Egypt the superiority of the Peronian squash variety significantly in the speed of emergence and number of femal flowers compared to the hybrid Mabroka.

Not long ago, researchers have been interested in alternatives to the chemicals that plants treat in order to increase productivity (AL-Leela et al., 2019), whether chemical fertilizers or industrial growth regulators, which may have potential negative effects on environmental pollution or on the public health of consumers, therefore in modern termed of agriculture has been focused on the use of seaweed extracts (Ibraheem, 2018), which are complementary to chemical fertilizers and not a substitute (Zodape et al., 2008), which is considered material that promotes the growth of plants in low concentrations, containing more than one group of substances encouraging 
growth such as auxins, gibberellins and cytokines on some major and minor nutrients in addition to containing some amino acids (Strick et al., 2003).

Helmy (1992) found that adding aqueous garlic extract to the side of pumpkin with a concentration of $2.5 \mathrm{ml} . \mathrm{L}^{-1}$ resulted in a significant increase in the number of female flowers and that spraying an alcoholic garlic extract with the same concentration increased the number of male flowers significantly. Hussien and ALRakabi (2006) founds that spraying garlic extract at a level of $2.5 \mathrm{~cm}^{3} \cdot \mathrm{L}^{-1}$ on the alphacucumber hybrid resulted in a significant decrease in the number of days needed for the first female flower to appear and a significant increase in the set ratio and sexual ratio. In a study by Jasim et al. (2006) for two consecutive seasons on snake cucumber, two types of extracts were used: garlic extract with a concentration of 0.5 and $1 \mathrm{ml} . \mathrm{L}^{-1}$ and licorice extract with a concentration of 0.5 and $1 \mathrm{~g} . \mathrm{L}^{-1}$ a significant increase was observed in the number of female flowers, set ratio and the sexual ratio when spraying licorice extract at a concentration of $1 \mathrm{~g} . \mathrm{L}^{-1}$ and at garlic at a concentration of $1 \mathrm{ml}$. $\mathrm{L}^{-1}$ for option only for the second season.

This experiment aims to study the behavior and evaluation of two squash hybrids under the conditions of Nineveh Governorate with the use of the seaweeds extract Acadian in order to improve the characteristics of flowering growth which leads to increased productivity and find the best overlap between the hybrids and the concentrations of the seaweed extract used under study.

\section{MATERIALS AND METHODS}

The experiment was carried out at a field of Horticulture and Landscape Department/ College of Agriculture and Forestry/Mosul University during spring growing season 2018 in sandy soil. The experiment study included the physiological effect of two factors, first included two hybrids of summer squash (MARVEL F1) and (ISMALIA F1) produced by Dutch company Enzazaden. Seeds germination 97\%, the second factor included the seaweed extract (Acadian) at three concentrations of $(0,2$ and $4 \mathrm{gm} . \mathrm{L}^{-1}$ ). derived from seaweed (Ascophyllum nodosum L.), which contains nitrogen, phosphorus, potassium and ash at $45-55 \%$. It also contains $20 \%$ organic material, Alginic acid 10\%, Manitol and Amino acid at 4\% each and 6.5\% moisture produced by Canadian Acadian sea plans company. Plants treated with above extracts during three stages of growth: the first was after the 3-5 real leaves appear on the plant and the second stage after two weeks of the first addition, while third stage was at the beginning of plants flowering. Therefore this experiment included 6 treatments carried out in the field using split-plots system in R.C.B.D design the hybrids placed in the 
main plots while the sub plots included Acadian extract levels, each treatment repeated three times. The land was divided into experimental units, which included 2 ridges of 2 $\mathrm{m}$ length and $1 \mathrm{~m}$ width per experimental unit. The seeds were planted on 15/3/2018 at a distance of $40 \mathrm{~cm}$ from one seed to another and in the upper half of the ridges and two seeds per hole and after full germination was the process of thinning to one plant in each hole. Drip irrigation system was used. The number of plants was 10 plants / experimental unit (30 plants per treatment.). Agricultural operations were carried out naturally and according to the recommendations used in the cultivation of summer squash to produce commercial fruits with attention to the process of irrigation and according to the need of the plant. Statistical analysis was conducted using program of SAS (Anonymous, 2017). Analysis of variance and Duncan's multiple range test at 0.05 were applied for all research data (AL-Rawi and Khlaf Allah, 2000).

\section{Studied characters}

1- The date of the first male and female flower appearing on the plant.

2- The number of male and female flowers per plant.

3- Sexual ratio.

4- Set ratio for female flowers.

\section{RESULTS AND DISCUSSION}

Table (1) shows the effect of hybrids and Acadian seaweed extract and their interaction on the characteristics of flowering growth. the results indicate that the plants of both hybrids Marvel and Ismailia did not differ significantly between them in all characteristics of studied flowering growth (the date of the appearance of the first male and female flower (day) on the plant, number of male and female flowers (flower.Plant ${ }^{-1}$ ), sexual ratio and set ratio of the female flowers). As for the effect of Acadian seaweed extract, the results indicate that the use of Acadian extract with both concentrations 2 and $4 \mathrm{~g}$. $\mathrm{L}^{-1}$ did not significantly affect each of the two characteristics of the appearing date of the first male flower on the plant and the number of the male flowers for each plant compared to the comparison treatment, and in relation to the date of the appearance of the first female flower on plants, the use of a concentration of 2 g. $\mathrm{L}^{-1}$ resulted in a significant decrease in this trait compared to the comparison treatment only. Whereas the use of both concentrations of this extract 2 and 4 g.L $\mathrm{L}^{-1}$ resulted in a significant increase in the number of females flowers and the sexual ratio as comparison with the comparison plants, and both treatments of the Acadian extract did not differ significantly between them in these two traits, and the treated plants 
showed a concentration of $4 \mathrm{~g} . \mathrm{L}^{-1}$ only from this extract was significantly superiority in the percentage of set ratio for flowers.

The results of the bilateral interaction between the hybrids and the Acadian extract indicate that there are no significant differences in the case of this interaction in the description of the date of the first male flower appearing on the plant, and that the smallest number of days for the appearance of the first female flower on the plant was 40.216 days found in the treatment of bilateral interaction between Ismaili hybrid plants and the concentration of 2 g. $\mathrm{L}^{-1}$ from the Acadian extract, so this treatment differed significantly with the treatment of comparison plants in the case of the Marvel hybrid. Also, no significant differences were observed between all treatments for this interference in the characteristic number of male flowers, and the use of Acadian extracts with both concentrations of 2 and $4 \mathrm{~g}$. $\mathrm{L}^{-1}$ for plants of both hybrids resulted in a significant increase in the number of female flowers compared to the Marvel hybrid plants and not treated with the seaweed extract. The highest sexual ratio was 2.073 obtained in the treatment of bilateral interference between the Marvel hybrid and the use of Acadian extract at a concentration of 4 g. $\mathrm{L}^{-1}$. Thus, this treatment differed significantly with the treatment of bilateral interference between the comparison plants for both hybrids. The Ismaili hybrid plants which treated at a concentration of 4 g.L $\mathrm{L}^{-1}$ of the seaweed extract gives the highest set ratio of 89.183 , thus this treatment differed

Table (1): Effect of hybrids, Acadian extracts and interaction between them on the flowering growth characteristics of summer squash.

\begin{tabular}{|c|c|c|c|c|c|c|c|}
\hline Hybrids & $\begin{array}{c}\text { Concentration } \\
\text { of seaweed } \\
\text { extract } \\
\text { (Acadian) }\end{array}$ & $\begin{array}{l}\text { date of the } \\
\text { first male } \\
\text { appearing } \\
\text { (day) }\end{array}$ & $\begin{array}{l}\text { date of the } \\
\text { first } \\
\text { female } \\
\text { appearing } \\
\text { (day) }\end{array}$ & $\begin{array}{l}\text { number of } \\
\text { male } \\
\text { flowers } \\
\text { per plant }\end{array}$ & $\begin{array}{l}\text { number of } \\
\text { female } \\
\text { flowers per } \\
\text { plant }\end{array}$ & $\begin{array}{l}\text { Sexual } \\
\text { ratio }\end{array}$ & $\begin{array}{l}\text { Set ratio for } \\
\text { female } \\
\text { flowers }\end{array}$ \\
\hline \multirow{3}{*}{ Marvel } & 0 gm. $\mathrm{L}^{-1}$ & $50.793 a$ & $50.066 a$ & $8.000 a$ & $12.167 b$ & $1.536 b$ & $81.997 a-c$ \\
\hline & $2 \mathrm{gm} . \mathrm{L}^{-1}$ & $45.970 a$ & $40.960 \mathrm{~b}$ & $7.722 a$ & $16.044 a$ & $1.976 a$ & $85.843 a b$ \\
\hline & $4 \mathrm{gm} . \mathrm{L}^{-1}$ & $49.364 a$ & $41.948 b$ & $7.444 a$ & $15.522 a$ & $2.073 a$ & $84.566 a b$ \\
\hline \multirow{3}{*}{ Ismailia } & 0 gm. $\mathrm{L}^{-1}$ & $50.846 a$ & $46.382 \mathrm{ab}$ & $7.888 a$ & $12.583 a$ & $1.642 b$ & $79.459 \mathrm{bc}$ \\
\hline & 2 gm. $\mathrm{L}^{-1}$ & $48.157 a$ & $40.216 b$ & $7.666 a$ & $16.066 a$ & $2.102 a$ & $74.606 c$ \\
\hline & $4 \mathrm{gm} . \mathrm{L}^{-1}$ & $48.959 a$ & $45.596 \mathrm{ab}$ & $7.666 a$ & $14.789 a$ & $1.941 a$ & $89.183 a$ \\
\hline \multirow{2}{*}{$\begin{array}{l}\text { Mean } \\
\text { effect of } \\
\text { hybrids }\end{array}$} & Marvel & $48.709 a$ & $44.324 a$ & $7.722 \mathrm{a}$ & $14.577 a$ & $1.895 a$ & $84.135 a$ \\
\hline & Ismailia & $49.320 a$ & $44.064 a$ & $7.740 a$ & $14.479 a$ & $1.861 a$ & $81.083 a$ \\
\hline \multirow{3}{*}{$\begin{array}{c}\text { Mean } \\
\text { effect of } \\
\text { seaweed } \\
\text { extract }\end{array}$} & 0 gm. $\mathrm{L}^{-1}$ & $50.819 a$ & $48.224 a$ & $7.944 a$ & $12.375 b$ & $1.589 b$ & $80.728 b$ \\
\hline & $2 \mathrm{gm} . \mathrm{L}^{-1}$ & $47.063 a$ & $40.588 b$ & $7.694 a$ & $16.055 a$ & $2.039 a$ & $80.224 b$ \\
\hline & $4 \mathrm{gm} . \mathrm{L}^{-1}$ & $49.162 a$ & $43.772 \mathrm{ab}$ & $7.555 a$ & $15.155 a$ & $2.007 a$ & $86.874 a$ \\
\hline
\end{tabular}

Means followed by the same letter or letters within column are not significantly different according Duncan test at $(\mathrm{P}<0.05)$. 
only significantly with comparison plants and plants treated with a concentration of 2 g. $\mathrm{L}^{-1}$ for the same hybrid.

Through what was reviewed from the results when discussing the results, it is clear that the Ismaili and Marvel hybrid plants did not differ significantly between them in all traits of flowering, while the Acadian seaweed extract factor for both hybrids used showed that it is the important and influencing factor in most of the traits of flowering growth and as its use led to significant results in many traits of flowering characteristics, and the treatments of seaweed extract at 2 and $4 \mathrm{~g} . \mathrm{L}^{-1}$ in most of the effects were not significant between them, and the significant effect on most traits of flowering growth (significant decrease of the appearing date of the first female flower on the plant as Its treatment is comparable to the Acadian extract at a concentration of $2 \mathrm{~g} . \mathrm{L}^{-1}$ and a significant increase in the number of female flowers and the sexual ratio shown when using this extract with both concentrations 2 and 4 g. $\mathrm{L}^{-1}$ and a significant increase in the percentage of set shown in the table when using the concentration 4 g.L ${ }^{1}$ of this extract may be due to the content of seaweed extracts of plant hormones such as auxins and cytokines that activate the physiological processes in the plant, which affects the characteristics of flowering. Stephenson (1986) stated that cytokines make the plant to flowers. O'Dell (2003) stated that spraying vegetable plants with marine extracts encourages early flowering in these plants, as well as containing these extracts on amino acids that play an important role in regulating biological processes and interfere with the formation of nucleotides, vitamins and growth hormones and enter into the synthesis of enzymes necessary for flower formation and for the richness of these extracts with nutrients made in the leaves during photosynthesis and their transition to effective growth areas, which encourages the production of the largest number of flowers and increases the proportion of sexual and sex ratio (AL-Obaidi, 2012). Moral significance in the characteristics of flower growth with many researchers who used plant extracts in vegetable fields, including (Helmy 1992; Masny and Zurawicz, 2004 and Hussien and AL-Rakabi, 2006).

It is concluded from this study that the Marvel and Ismaili hybrid plants did not differ significantly between them in all studied flowering growth characteristics, which indicates the feasibility of adopting these two hybrids for growing squash crops in Nineveh Governorate, with recommendations to evaluate hybrids and other varieties, especially those characterized by early flower production, with the aim of increasing economic viability. The Acadian seaweed extract factor in both hybrids used showed that it is the important and influencing factor in most of the studied traits, as its use led to significant results in many traits of flower growth. This study recommends conducting other future research using concentrations higher than 4 g. $\mathrm{L}^{-1}$ from this extract and comparing it with the concentrations used in this study, as well as the use of this extract with other vegetable crops for its positive role in the characteristics of flowering. 
تأثثر المستخلص البحري (الاكاديان) في بعض صفات النمو الزهري لصنفين من قرع الكوسه

\title{
Cucurbita pepo $\mathrm{L}$.
}

\author{
قبس بسام عبدالله الحيالي \\ فاضل فتحي رجب الحديدي \\ قسم البستنة وهندسة الحدائق/ كلية الزر اعة والغابات / جامعة الموصل / العراق
}

Fathel_way@yahoo.com

\section{الخلاصة}

نفذت التجربة في حقل خضراوات قسم البستنة وهندة الحدائق/كلية الزراعة والغابات/جامعة الموصل خلال الموسم الربيعي (2018). تضمنت التجربة دراسة عاملين: الاول هجينين من قرع الكوسه هما: الهجين مارفل (MARVEL) والهجين اسماعيلية (ISMALIA) والعامل الثاني اشتمل على المستخلص البحري

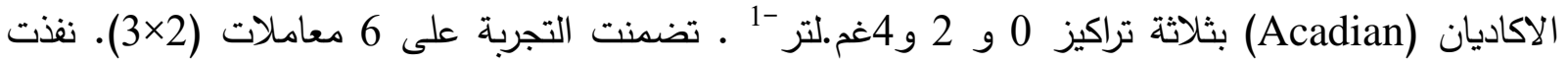
التجربة في الحقل باستخدام نظام القطع المنثقة (split-plots Design) في تصميم القطاعات العشوائية الكاملة R.C.B.D الثانوية (Sub plots) وكررت كل معاملة ثلاث مرات. تم اختيار جميع النتائج احصائيا حسب اختبار دنكن متعدد الحدود عند مستوى احتمال 5\%. يمكن تلخيص اهم النتائج بما يلي: لم تختلف نباتات الهجينين مارفل واسماعيلية في جميع صفات النمو الزهري الددروسة (موعد ظهور اول زهرة مذكرة ومؤنثة على النبات (يوم) وعدد

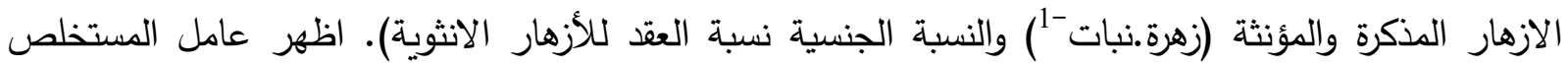

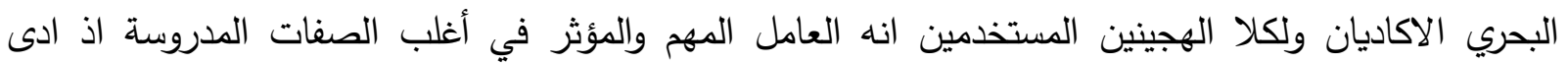
استخدامه الى نتائج معنوية في العديد من صفات النمو الزهري ولم تختلف معاملتا المستخلص البحري 2 و4 غم.لتر -1 في أغلب التأثيرات معنويا فيما بينهما. الكلمات المفتاحية: المستخلص البحري أكادين، قرع الكوسه، الهجين، الازهار الذكرية، الازهار الانثوية.

$$
\text { تاريخ تسليم البحث : } 29 \text { /2 / 2020 وقبوله : } 23 \text { /4 / } 2020
$$

\section{REFERENCES}

Anonymous, (2017). Statistical Analysis System. SAS Institute. Inc. Cary Nc. 27511, USA.

AL-Rawi, KH.M. and A.A.M. Khlaf Allah (2000). Design and Analysis of Agricultural Experiment. Mosul University. Ministry of Higher Education and Scientific Research. National Library. Iraq. 
AL-Leela, W.B.; H.J.M.AL-Bayati and F.F. Rejab (2019). Effect of chemical and organic fertilizer on three varieties of broad bean. Mesopotamia Journal of Agriculture, 47(2):73 - 82 .

AL-Obaidi, A.A.H. (2012). Effect Of Plant Extracts On Morphological Characteristics And Productivity Of Tomato Planted In Greenhouse. Ph.D. Thesis. Faculty of Agriculture, AL Baath University, Syria.

Ercon, N. and R. Kurum (2003). Plant, flower, fruit and seed characteristics of five generation inbred summer squash lines (cucurbita pepo L .). Pakstan Journal of Botany, 35(2 237-241.

Gossell, W.M.; A. Davis and N.O. Connor (2007). Sprague dawley rate pumpkin seed oil. Journal of Medical Food, 9:284-286.

Helmy, E.M. (1992). Response to summer squash application methods of fresh Garlic extract by different solvent. Agriculture. Egypt Research, 37(3):12-14.

Hussien, W.A. and F.H. AL-Rakabi (2006). Effect of spraying with garlic extract, licorice root extract or urea on flowering characters and yield of cucumber (Cucumis sativus L.). The Iraqi Journal of Agricultural Sciences, 37(4):27-32.

Jasim., A.M.; A.N. Jary and M.H. Fiayd (2006). Effect of spraying plant extracts and growth reticulates on flowering of snake cucumber and cucumber. Journal of Karbala University, 5(4):204-211.

Ibraheem, F.F.R. (2007). Effect Of Planting Dates And Foliar Application Of Gibberllic Acid On Vegetative Growth, Quantity And Quality Of Yield In Two Cultivars Of Cauliflower (Brassica oleracea var. botrytis). M.Sc Thesis. Faculty of Agriculture and Forestry, Mosul University, IRAO.

Ibraheem, F..F.R. (2018).Response of tow potato cultivars to humic acid fertilizer. Mesopotamia Journal of Agriculture, 46(2):54 - 61.

Khadem, M.H. and H.A. Hussein (2015). Effect of peat moss source treated with poultry suspension on growth and yield of two hyprid (Cucurbita pepo L.). ALForat Journal of Agricultural Sciences, 7(3):148-156.

Kolato, E and A. Balbierz (2015). Yield potential and fruit quality of scallop squash cultivars grown for processing. Acta Agrobotanica, 68(3):261-266.

Masny, A.B. and E. Zurawicz (2004). Effect of application of kalpak sland gore mar BM86 preparation on yield and fruit quality in two strawberry cultivars. Journal of Pomologicazn, 18:96-100.

Mohamed, G.H. (2003). Effect Of Foliar Application Of Potassium And IAA On Growth And Yield Of Five Varieties of Squash (cucuribita pepo L.). M.Sc. Agricultural Science, Horticulture, University of Dohuk.

Nesmith, D.S.; G. Hoogenboom and D.W. Groff (1994). Staminate and distillate flower production of summer squash in response to planting date. Hort Science, 29(4):256-257. 
O'Dell, C. (2003). Natural plant hormones are bio stimulates helping plant develop high plant antioxidant activity for multiple benefits. Vieginia Vegetable Small Friut and specialty Crop, 2(6):1-3.

Radiya, K.S.S. (2004). Effect Of Plant Population, Bio-fertilizer And Nitrogen On Growth, Fruit, Yield, Seed Production And Seed Quality Of Summer Squash . Ph.D. Thesis, Faculty of Agriculture, Alexandria University, Egypt.

Shalaby, G.I.; E.F.S. Rafaei and M.F. Mohamed. (2003) Growth and yield of inbred zucchinl squash (Cucuribita pepo L.) lines developed under adverse climatic conditions. Bull Environmental Research, 6(1):55-62.

Stephenson, W. (1986). Seaweed in Agriculture and Horticulture. Seaweed and Plant Growth, Chapter 7. htpp://WWW.Amma .Assn.Org.

Strick, W.A.; M.S. Novak and J. Vanstaden (2003). Cytokines in macro algae. Plant Growth Regulator, 41:13-24.

Zodape, S.T.; V.J. Kawarkh; J.S. Patolia and A.D. Warade (2008). Effect of liquid seaweed fertilizer on yield and quality of okra Abelmoschus esculentus. Journal of Scientific and Industrial Research, 67:1115-1117. 